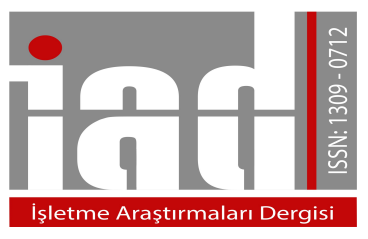

İşletme Araştırmaları Dergisi Journal of Business Research-Turk 10/3 (2018) 1-14

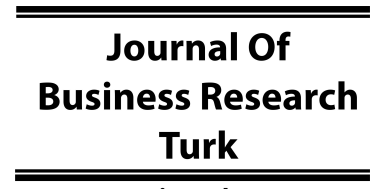

www.isarder.org

\title{
A Financial Analysis of the Liquidity Creation and the Capital Holdings of Turkish Banks
}

\author{
Gamze OZTURK DANISMAN \\ Bogazici University \\ Department of Management \\ Istanbul, Turkey \\ orcid.org/0000-0003-3684-6692 \\ danisman.gamze@gmail.com
}

\begin{abstract}
In this paper, the impact of the amount of bank capital on the bank liquidity creation is explored using a sample of 21 Turkish banks and quarterly data for the period 2010Q1-2017Q4. Our methodology involves fixed effects panel data estimation techniques and we use lagged independent variables to control for endogeneity. Our findings indicate that the liquidity creation of Turkish banks has dramatically increased over time and it is primarily driven by large banks. Our results from the regression analysis indicate that bank liquidity creation is increased under higher levels of capital for the whole sample. While a higher level of bank capital increases bank liquidity for small banks, the opposite case occurs for large banks, namely, the created liquidity decreases by more bank capital. We offer some important policy implications in that while regulators in the emerging markets impose capital requirements on banks, they need to consider the impact on liquidity creation of banks of different sizes.
\end{abstract}

Keywords: Liquidity creation, Bank capital, Regulations, Turkish banks

\section{Introduction}

Banks have crucial functions in the economy with the most important ones including liquidity creation and risk transformation (Bhattacharya and Thakor, 1993). Banks finance relatively illiquid loans with liquid deposits and thereby contribute to the liquidity creation and growth in the economy (Diamond and Dybvig, 1983) and perform a risk transformation (Diamond, 1984; Ramakrishnan and Thakor, 1984). As mentioned by Berger and Bouwman (2009), when risky illiquid loans are financed with liquid deposits; the different functions of liquidity creation and risk transformation actually do coincide. However, these two functions are indeed different since the level of liquidity creation varies for different levels of risk taken by banks. The majority of the empirical literature study the risk transformation function of banks with relatively fewer ones focusing on the liquidity creation. 
While banks' decision to hold capital mainly originates from their risk transformation roles, the amount of liquidity is also affected by the amount of bank capital (Berger and Bouwman, 2009). The impact of bank capital on the creation of liquidity is ambiguous in the literature. One strand of the literature, which is called the "financial fragility-crowding out" hypothesis, claims that holding more capital decreases banks' ability to create liquidity by inducing a less fragile capital structure and by crowding out deposits (Diamond and Rajan 2000; Gorton and Winton, 2017). The opposing "risk absorption" hypothesis, on the other hand, states that higher capital absorbs risks and lets banks to provide more liquidity to the economy (Bhattacharya and Thakor 1993; Von Thadden 2004).

As mentioned by Berger and Bouwman (2009), which of these two views dominates relies on different bank characteristics such as the relative size of banks. In this paper, we explore the impact of bank capital on liquidity creation in the context of an emerging market, Turkey. We investigate the variation in the bank capital-liquidity creation relationship considering the differences between small and large banks. The empirical studies that investigate the link between bank capital and liquidity creation are quite rare. To our knowledge, we provide a first attempt to study this relationship in Turkey, which is where we want to contribute to the literature. We further want to contribute to the literature by deepening our understanding of the role of bank capital on liquidity creation and how this relationship may vary for small and large banks in the context of emerging markets.

Turkish banking system brings an interesting environment to study bank capitalliquidity creation relationship. The banking sector is the cornerstone of the Turkish financial system with total banking sector assets constituting around $90 \%$ of the total financial system in Turkey (IMF, 2017). Therefore, it can be stated that the Turkish financial system is strongly bank dominated. Nonbank financial intermediaries in Turkey are small compared to peer emerging markets. Since 2008, the Turkish financial system is growing faster than the GDP which is at 118\% of GDP by 2015 (IMF, 2017). The banking market share is equally distributed between domestic, foreign and public banks. Turkish economy was quite fragile in the late 1990s with high inflation rates and budget deficits which further led to the economic crisis of 2001. At the beginning of the 2000s, many Turkish banks got into trouble and were not able to expand any credit to the economy. These banks were either insolvent or got engaged in consolidations. Thereafter, a stabilization program was initiated together with the International Monetary Fund aiming to reduce inflation and spur economic growth (Akyüz \& Boratav, 2003). Since then, a stable macroeconomic environment has been reached in Turkey with an average GDP growth of $6.88 \%$ between the years 2010-2017.

In our empirical analysis, we explore the impact of the amount of bank capital on bank liquidity creation utilizing a sample of 21 Turkish banks and using quarterly data for the period 2010Q1- 2017Q4. Our methodology involves fixed effects panel data estimation techniques. Due to endogeneity concerns, we use lagged independent variables. As mentioned by Berger and Bouwman (2009), the variation in bank size is expected to influence our results and we explore this by splitting the sample into two subsamples of large and small banks. We employ the liquidity creation measure constructed by Deep and Schaefer (2004) which is calculated as the ratio of the liquid liabilities minus liquid assets to the total bank assets. A higher amount of liquidity transformation is achieved by higher values of this ratio. 
We observe from our findings that the link between bank capital and liquidity varies by size in the Turkish context which offers some policy implications for emerging markets. Bank regulators aim to preserve the soundness of the banking system by imposing capital restrictions. However, while capital requirements would bring safety and soundness for all banks in the emerging markets like Turkey, the implications for liquidity creation in the economy would differ for banks with different sizes which need to be taken into consideration by regulators. The general implication is that, while imposing capital requirements to banks, regulators need to consider the different bank size classes and arrange the regulations accordingly when considering its impact on the liquidity created by banks in the system. More stringent capital requirements on large banks could lead to a decrease in their liquidity creation which would hamper economic growth in emerging markets. On the other hand, the more stringent capital requirements on small banks help to enhance their risk-absorbing capacity and increase their liquidity creation by making them safer. The remainder of the paper is outlined as follows: Section 2 provides a review of the literature and Section 3 presents the data and methodology. Results are provided in Section 4 and finally, Section 5 concludes.

\section{Literature Review}

The main motivation for bank capital is to be protected from the risks such as the risk of bank runs, credit risk, and to transform their risks. Recent theories, on the other hand, state that the amount of capital held by banks may impact their creation of liquidity. The theoretical literature on the influence of bank capital on the amount of bank liquidity created has two different views.

The "financial fragility-crowding out" hypothesis states that bank liquidity creation is raised with higher levels of capital. The theoretical model of Diamond and Rajan (2000) claim that banks obtain borrower-specific information while monitoring the borrower and collecting the payments. However, an agency problem may occur in the course of relationship when banks demand a greater share of loan income at the expense of depositors. To prevent the risk losing the trust of depositors, banks need to conduct a fragile financial structure which is characterized by a larger share of liquid deposits and loans, and lower capital, which results in more liquidity creation. In other words, as financial fragility is decreased by more capital, liquidity creation is reduced in turn. It is worthwhile to note that the findings of Diamond and Rajan (2000) hold when the deposit insurance mechanism is incomplete. Another argument under "financial fragility-crowding out" hypothesis is put forward by Gorton and Winton (2017). They state that the crowding out effect for deposits occurs with higher levels of capital which results in a decrease in liquidity creation. Their argument is that deposits are more favorable for the bank liquidity needs as compared to equity capital because deposits are liquid and easy to withdraw.

The alternative "risk absorption" hypothesis is based on the risk-transformation roles of banks and argues that liquidity creation is enhanced with more capital. The main argument is that bank risk rises with increased liquidity creation (Allen and Santomero 1997; Allen and Gale 2004). They claim that the likelihood of losses that result from disposing of illiquid assets and meeting the liquidity demands of depositors is increased when there is a rise in liquidity creation. Another argument is that bank's 
risk-absorbing capacity is enhanced with more capital (Bhattacharya and Thakor 1993; Von Thadden 2004).

The empirical studies on the link between bank capital and liquidity creation are quite limited. Bank lending decreased in the early 1990s which initiated a discussion on the impact of bank capital on bank lending. Some studies found that the reduction in bank equity ratios has resulted in a decrease in bank lending (Peek and Rosengren, 1995). On the other hand, other studies found that the more stringent leverage requirements in the 1990s, such as Basel I, led to the decrease in lending (Berger and Udell, 1994). Other empirical studies in the literature cover different aspects of liquidity creation. For instance, Berger and Udell (2004) observe that the annual growth of business loans increases with more capital. Holod and Peek (2007) further find that loan growth is exacerbated with more bank capital.

The direct relationship between bank capital and liquidity relationship is first explored by Berger and Bouwman (2009) in a seminal study which investigates the liquidity creation of US commercial banks from 1993 to 2003. They specifically explore how much liquidity is created by banks and the cross-sectional variations in the liquidity creation. They create four new measures for liquidity creation of banks which differ in terms of the classification of loans and off-balance sheet treatments. Their findings indicate that there is an increase in the liquidity creation every year in the US banking industry from 1993 to 2003. The banks that generate the highest liquidity are larger banks. As bank value increases, liquidity creation also rises. They further find that the "risk absorption" hypothesis holds for large banks where more capital is found to increase liquidity creation. On the other hand, the "financial fragility-crowding out" hypothesis holds for small banks where higher levels of capital let small banks to create more liquidity.

Fungáčová et al. (2017) explore the link between bank capital, deposit insurance and liquidity creation using a dataset on an emerging market, Russia. Their findings indicate that there exists a negative relationship between the level of bank capital and liquidity creation, supporting "financial fragility-crowding out" hypothesis, which also holds under deposit insurance mechanism. Considering the different size classes of Russian banks, they observe that the negative relationship prevails for banks with small and medium sizes. Horvath et al. (2012) explore the impact of bank capital on liquidity creation utilizing a sample of Czech banks between 2000-2010. Their findings indicate that increased bank capital negatively decreases the liquidity created but more liquidity causes a reduction in bank capital as well.

\section{Data and Methodology}

\subsection{Methodology}

We examine the impact of bank capital on the liquidity transformation using fixed effects panel data estimation techniques to observe whether the "financial fragilitycrowding out" or the "risk absorption" hypotheses dominate. To consider the impact of reverse causality and endogeneity, following Berger and Bouwman (2009) and Fungáčová et al. (2017), we use lagged independent variables in the model. Since we have a limited number of quarters and observations, following Fungáčová et al. (2017), we only use a lag of one quarter for limiting the decrease in observations. We regress the liquidity creation measure on the independent variables that capture the bankspecific and macroeconomic factors that may potentially affect the relationship. We 
include bank fixed effects to consider the heterogeneity between banks. Bank-level clustered robust standard errors are used to account for heteroskedasticity and autocorrelation. Time fixed effects are also captured by including a dummy variable for each quarter between 2010Q1 and 2017Q4 in the model to control for the differences between quarters.

In our analysis, we split the sample into subsamples by considering the differences between large and small banks because the variation in the sizes of banks is expected to influence our results. For instance, Berger et al. (2005) state that large banks have different types of loan structures as compared to smaller ones because they do have comparative advantages in different loans. Moreover, Berger and Bouwman (2009) find empirical evidence that the impact of capital on liquidity creation differs between small and large banks for US banks. We define banks as "large" if their total assets are above the median of total assets of all banks, i.e. above 43.35 trillion TL. Conversely, banks are defined as "small" if their total assets are below the median, i.e. below 43.35 trillion TL.

\subsection{Data}

The primary source of bank level data is Fitch Connect Database from Fitch Solutions ${ }^{1}$. We utilize quarterly data on 21 Turkish commercial banks for the years 2010-2017. The list of banks included in the study is provided in Table A in the Appendix. The data for macroeconomic variables are obtained from the Turkish Statistical Institute. The definition of the variables is summarized in Table 1 and the descriptive statistics for the variables are displayed in Table 2. All data are expressed in Turkish Lira (TL). Bank size is the only variable that is expressed in levels and it is calculated in constant 2010 TL to take away the effect of inflation.

\section{Table 1: Definition of the variables}

\begin{tabular}{ll}
\hline Name of variables & Description \\
\hline $\begin{array}{l}\text { Panel } \boldsymbol{A} \text { : Dependent variable } \\
\text { Liquidity creation }\end{array}$ & (Liquid liabilities - Liquid assets)/ Total assets \\
Panel B: Bank Controls & Ln (total assets) \\
Bank size & Shareholders equity / total assets \\
Equity to total assets & Ln ((ROA+ Equity to assets)/ $\sigma(\mathrm{ROA}))$ \\
Z-score & Nonperforming loans to gross loans \\
NPLs & \\
Panel C: Macroeconomic variables & \\
Real GDP growth & Annual growth rate of GDP \\
Inflation & The annual growth rate of the GDP implicit deflator \\
\hline Note: This table shows the brief descriptions of the variables.
\end{tabular}

Note: This table shows the brief descriptions of the variables.

\footnotetext{
${ }^{1}$ The author would like to thank Dr. Pelin Demirel for providing the dataset for the study.
} 
G. Ozturk Danisman 10/3 (2018) 1-14

Table 2: Descriptive Statistics

\begin{tabular}{|c|c|c|c|c|c|c|}
\hline Variable & $\mathrm{N}$ & Mean & Min & $\operatorname{Max}$ & Median & Stand. Dev. \\
\hline \multicolumn{7}{|l|}{ Panel A: All banks } \\
\hline Liquidity Creation & 612 & $35.21 \%$ & $-18.04 \%$ & $99.01 \%$ & $39.05 \%$ & $20.47 \%$ \\
\hline Total assets (millions) & 622 & $90,650.43$ & 879.70 & $456,926.10$ & $43,349.58$ & $100,203.30$ \\
\hline Equity to Total assets & 622 & $10.72 \%$ & $5.52 \%$ & $22.76 \%$ & $10.45 \%$ & $2.37 \%$ \\
\hline Ln(Z-score $)$ & 590 & 4.38 & 1.59 & 7.79 & 4.31 & 0.96 \\
\hline NPLs & 621 & $3.41 \%$ & $0.89 \%$ & $11.40 \%$ & $3.07 \%$ & $1.54 \%$ \\
\hline Inflation & 672 & $8.48 \%$ & $6.16 \%$ & $11.92 \%$ & $8.35 \%$ & $1.83 \%$ \\
\hline Real GDP growth & 672 & $6.84 \%$ & $3.18 \%$ & $11.11 \%$ & $6.74 \%$ & $2.37 \%$ \\
\hline \multicolumn{7}{|l|}{ Panel B: Small banks } \\
\hline Liquidity Creation & 304 & $25.43 \%$ & $-18.04 \%$ & $65.60 \%$ & $18.55 \%$ & $20.60 \%$ \\
\hline Total assets (millions) & 311 & $16,446.73$ & 879.70 & $43,152.10$ & $13,673.78$ & $11,897.56$ \\
\hline Equity to Total assets & 311 & $11.04 \%$ & $5.52 \%$ & $22.76 \%$ & $10.55 \%$ & $2.98 \%$ \\
\hline $\operatorname{Ln}(Z$-score $)$ & 290 & 4.25 & 1.59 & 7.79 & 4.21 & 1.03 \\
\hline NPLs & 310 & $3.79 \%$ & $0.91 \%$ & $11.40 \%$ & $3.45 \%$ & $1.74 \%$ \\
\hline Inflation & 311 & $8.49 \%$ & $6.16 \%$ & $11.92 \%$ & $8.17 \%$ & $1.80 \%$ \\
\hline Real GDP growth & 311 & $6.80 \%$ & $3.18 \%$ & $11.11 \%$ & $6.09 \%$ & $2.40 \%$ \\
\hline \multicolumn{7}{|l|}{ Panel C: Large banks } \\
\hline Liquidity Creation & 308 & $44.86 \%$ & $13.99 \%$ & $99.01 \%$ & $48.47 \%$ & $15.08 \%$ \\
\hline Total assets (millions) & 311 & $164,854.10$ & $43,547.07$ & $456,926.10$ & $146,723.00$ & $94,468.75$ \\
\hline Equity to Total assets & 311 & $10.39 \%$ & $6.75 \%$ & $14.95 \%$ & $10.37 \%$ & $1.48 \%$ \\
\hline Ln(Z-score) & 300 & 4.50 & 2.48 & 7.47 & 4.39 & 0.87 \\
\hline NPLs & 311 & $3.05 \%$ & $0.89 \%$ & $6.77 \%$ & $2.86 \%$ & $1.21 \%$ \\
\hline Inflation & 361 & $8.47 \%$ & $6.16 \%$ & $11.92 \%$ & $8.53 \%$ & $1.86 \%$ \\
\hline Real GDP growth & 361 & $6.88 \%$ & $3.18 \%$ & $11.11 \%$ & $7.40 \%$ & $2.35 \%$ \\
\hline
\end{tabular}

Note: The table shows summary statistics for the variables. While Panel A lists the descriptive statistics for all the sample; Panel B and C displays the summary statistics for small and large banks, respectively.

\subsubsection{Dependent variable}

As indicated in Section 2; Berger and Bouwman (2009), in a seminal paper, constructed four new measures for liquidity creation of banks which differ in terms of the classification of loans and off-balance sheet treatments. Specifically, their four measures classify loans and bank activities based on category or maturity. However, Deep and Schaefer (2004) had provided a first attempt in the literature to measure liquidity creation and measure it simply as the ratio of the difference between liquid liabilities and liquid assets to the total bank assets. This measure is called the liquidity transformation gap (LT gap) and it is conceptually close to the "mat nonfat" measure of Berger and Bouwman (2009). In our analysis, the liquidity creation measure constructed by Deep and Schaefer (2004) is utilized due to data limitations on constructing Berger and Bouwman (2009) measures. A higher amount of liquidity transformation is indicated by higher values of this ratio. For instance, a bank that has a large portion of liquid deposits and illiquid loans would have a higher LT gap. While calculating this measure, Deep and Schaefer (2004) consider the assets and liabilities maturing in less than one year where they attempt to measure whether liquid liabilities are being able to convert into productive capital rather than being prone to bank runs. We follow their approach and consider all assets and liabilities maturing in less than one year while 
calculating liquid assets and liabilities. Specifically, our liquid assets measure covers all loans and advances, interbank loans and advances and trading assets at fair value through income maturing in less than one year. Our liquid liabilities measure, on the other hand, cover all retail, interbank and other types of deposits maturing in less than one year.

Table 2 displays the descriptive statistics of the liquidity creation measure. We observe that the liquidity creation measure in all our sample ranges from $-18.04 \%$ to $99.01 \%$, with an average of $35.21 \%$ and a standard deviation of $20.47 \%$. Liquidity creation average is observed to be higher for large banks in comparison to small banks; $44.86 \%$ and $25.43 \%$ respectively. Therefore large banks in Turkey are found to create a lot more liquidity to the market compared to small banks and liquidity creation in Turkish banking is primarily driven by large banks. Figure 1 presents the quarterly evolution of liquidity transformation measure for the whole sample where a strong rise in liquidity creation is observed through the years. It is clearly seen that the mean liquidity creation ratio of Turkish banks has increased dramatically over time from $29 \%$ in 2010 Q1 to $41 \%$ in 2017 Q4.

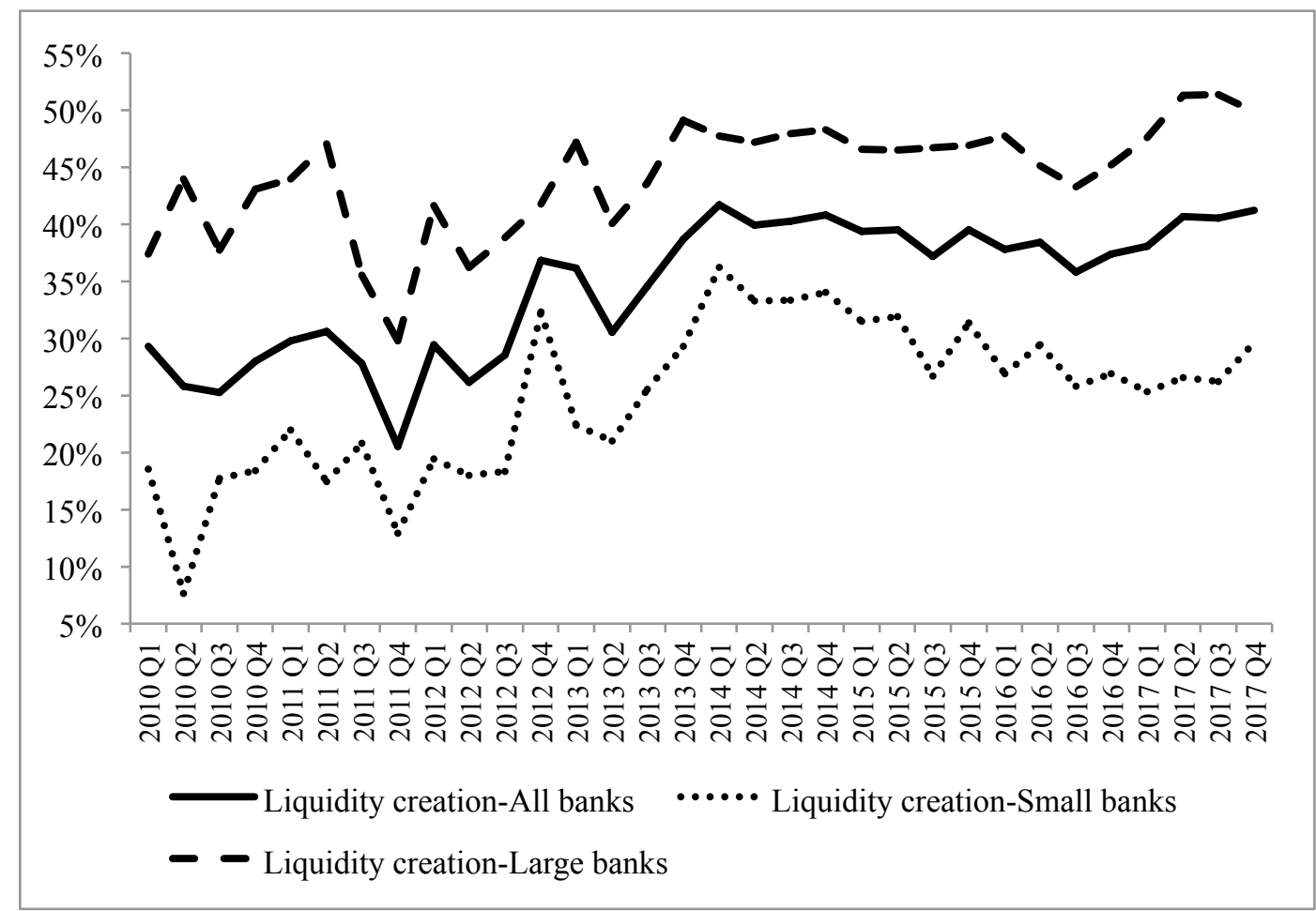

Figure 1: The figure shows the quarterly evolution of the liquidity creation measures for the period 2010Q1-2017Q4 for all banks, and the subsamples of small banks and large banks, respectively.

Figure 1 further displays the quarterly evolution of liquidity creation for the subsamples of large and small banks. It is again evident from the figure that more liquidity is created by large banks in comparison to small banks and both subsamples have increased their liquidity creation over time. While the liquidity creation of small banks increased from $19 \%$ in $2010 \mathrm{Q} 1$ to $30 \%$ in $2017 \mathrm{Q} 4$; the liquidity creation of large banks rose from $37 \%$ in $2010 \mathrm{Q} 1$ to $50 \%$ in $2017 \mathrm{Q} 4$. 


\subsubsection{Independent variables}

The independent variables are chosen from the extant literature, mainly following Berger and Bouwman (2009). We control for two sets of factors which are bankspecific and macroeconomic factors. The equity capital ratio is our independent variable of interest. The impact of capital on liquidity creation is found to be driven by banks' risk transformation roles, therefore, we control for two different dimensions of bank risk: credit risk and default risk. It is very crucial to control for bank risk because banks hold capital to absorb their risks and we are able to isolate the role of bank capital on liquidity accordingly. We further control for bank size to account for the different sizes of banks. The macroeconomic variables that are considered in the analysis include real GDP growth and inflation.

- Equity capital ratio: We control for the equity capital ratio which constitutes our main independent variable of interest in the analysis. The shareholders' equity to total assets is used in the calculation of the equity capital ratio. Table 2 displays that equity ratio ranges from $5.52 \%$ to $22.76 \%$, with an average of $10.72 \%$ and a standard deviation of $2.37 \%$ for the whole sample. While for small banks, the equity ratio ranges from $5.52 \%$ to $22.76 \%$ with an average of $11.04 \%$; the ratio ranges from $6.75 \%$ to $14.95 \%$ with an average of $10.39 \%$ for the large banks. Hence, we observe that the mean equity ratio for large banks is slightly lower than the equity ratio of small banks.

Figure 2 presents the quarterly evolution of the equity ratios for the whole sample where we observe a decreasing trend in equity ratios. It is seen that the mean equity ratio has increased only for the years 2010 and 2012 but in general shows a decreasing pattern over time from $11.82 \%$ in 2010 Q 1 to $9.62 \%$ in 2017 Q4.

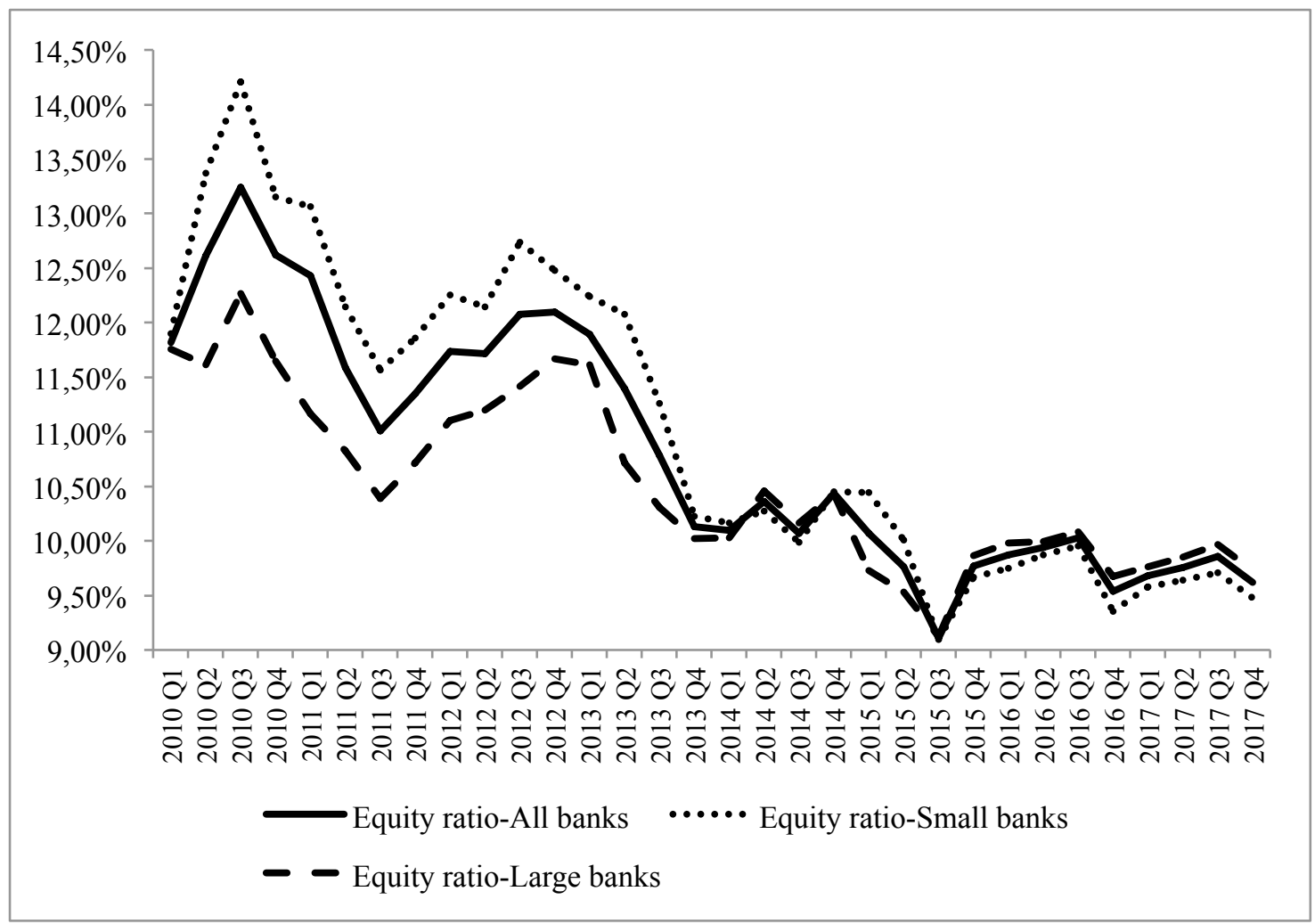

Figure 2: The figure shows the quarterly evolution of the equity ratios for the period 2010Q12017Q4 for all banks, and the subsamples of small banks and large banks, respectively. 
Figure 2 further displays the quarterly evolution of the equity ratios for the large and small banks. While small banks had somewhat higher equity ratios than large banks for the period 2010Q1-2013Q4; their equity ratios got very close to each other after 2014Q1.

- NPL ratio: We control for bank credit risk by using the non-performing loans ratio as a proxy. The definition of NPL ratio employed in the analysis is the ratio of non-performing loans to gross loans. Table 2 displays that NPLs ratio ranges from $0.89 \%$ to $11.40 \%$, with an average of $3.41 \%$ and a standard deviation of $1.54 \%$ for the whole sample. While for small banks, the NPLs ratio ranges from $0.91 \%$ to $11.40 \%$ with an average of $3.79 \%$; the ratio ranges from $0.89 \%$ to $6.77 \%$ with an average of $3.05 \%$ for large banks. Hence, large banks have a slightly lower ratio of capital to total assets compared to large banks.

- Z-score: The default risk is captured by using the Z-score as a control variable (Roy, 1952) with higher values imply a lower bankruptcy risk. It is calculated as:

$$
\mathrm{Z}_{\mathrm{it}}=\frac{\mathrm{ROA}_{\mathrm{it}}+\left(\mathrm{E} / \mathrm{A}_{\mathrm{it}}\right)}{\sigma(\mathrm{ROA})_{\mathrm{it}}}
$$

where ROA and $\sigma(\mathrm{ROA})$ show the return on assets and its standard deviation, respectively. E/A is the equity-to-asset ratio. Since it is skewed, the natural logarithm transformation of the Z-score is used. Table 2 indicates that $\ln$ (Z-score) ranges from 1.59 to 7.79 with an average of 4.38 and a standard deviation of 0.96 . The mean value for the Z-score is observed to be lower for small banks in comparison to large banks, namely 4.25 and 4.50 , respectively. Therefore, small banks are found to capture more bank default risk compared to large banks.

- Size: We control bank size as the natural logarithm of total assets and since it is highly skewed, the variable is taken in the natural logarithm.

- Real GDP growth: It is calculated as the annual percentage growth of GDP and controls for economic growth. The real GDP growth for Turkey between the years 2010 to 2017 ranges from $3.18 \%$ to $11.11 \%$ with an average of $6.84 \%$ and a standard deviation of $2.37 \%$.

- Inflation: It is defined as the annual growth rate of the GDP implicit deflator. The inflation rate for Turkey between the years 2010 to 2017 ranges from $6.16 \%$ to $11.92 \%$ with an average of $8.48 \%$ and a standard deviation of $1.83 \%$.

Table 3 displays correlation coefficients which show no indication of multicollinearity problem. 
Table 3: Correlations

\begin{tabular}{lccccc}
\hline & $\begin{array}{c}\text { Equity to } \\
\text { total assets }\end{array}$ & Size & ln (Z-score) & NPLs & $\begin{array}{c}\text { Inflation } \\
\text { Real GDP } \\
\text { growth }\end{array}$ \\
\hline Equity to total assets & 1 & & & & \\
Size & $-0.3541^{*}$ & 1 & & & \\
$\ln (Z$-score $)$ & $0.0933^{*}$ & $0.1432^{*}$ & 1 & & \\
NPLs & $0.1394^{*}$ & $-0.2369^{*}$ & $-0.1766^{*}$ & 1 & 1 \\
Inflation & $-0.2429^{*}$ & $0.1167^{*}$ & 0.0687 & -0.0645 & 1 \\
Real GDP growth & $0.1795^{*}$ & $-0.0977^{*}$ & -0.0579 & 0.0201 & $0.2875^{*}$ \\
\hline $\begin{array}{l}\text { Note: This table shows the correlation coefficients among independent variables. } \\
\text { * significance at } 0.05\end{array}$ & & & & \\
\end{tabular}

\section{Results}

Table 4 shows our regression results. While Column 1 displays the results for the whole sample, the results for small and large banks are presented in Columns 2 and 3, respectively. We employ fixed effects panel data estimation by employing bank-fixed effects. Our aim is to see which of the "financial fragility-crowding out" or the "risk absorption" hypotheses are prevalent in our sample. Lagged independent variables are utilized in the empirical model to account for reverse causality and endogeneity problems. Standard errors are clustered at the bank level to consider any heteroskedasticity and autocorrelation. Quarter fixed effects are also included by using a dummy variable for each quarter between 2010Q1 and 2017Q4 in the model to control for time differences.

Results from Column 1 indicate that a higher level of bank capital increases bank liquidity creation for the whole sample. The result is consistent with the "risk absorption" hypothesis which states that higher level capital held by banks lets banks to provide more liquidity to the economy by absorbing risks (Allen and Gale, 2004).

As stated in the Methodology section, our sample is split into two subsamples which include small and large banks because the variation in the sizes of banks is expected to influence our results. "Large" banks are accepted as the ones whose total assets are above the median of total assets, i.e. above 43.35 trillion TL. "Small" banks, on the other hand, are defined as the ones below the median of total assets, i.e. below 43.35 trillion TL. Results from Column 2 indicate that a higher level of bank capital increases bank liquidity creation for small banks, in line with the "risk absorption" hypothesis. However, Column 3 shows that the opposite case occurs for large banks, namely higher level of bank capital decreases bank liquidity creation for large banks, consistent with the "financial fragility-crowding out" hypothesis which claims that liquidity created by banks decreases by holding more capital by making the capital structure more stable (Diamond and Rajan 2000) and by crowding out deposits (Gorton and Winton, 2017). Therefore, our analysis indicates that the "risk absorption" hypothesis dominates for small banks and "financial fragility-crowding out" hypothesis dominates for large Turkish banks. 
Table 4: Regression results

\begin{tabular}{lccc}
\hline & (1) All banks & (2) Small banks & (3) Large banks \\
\hline L.Equity to Total assets & $1.151^{* *}$ & $2.734^{* * *}$ & $-4.295^{* * *}$ \\
L.Size & -0.55 & -0.803 & -0.955 \\
& $0.115^{* *}$ & $0.155^{* *}$ & 0.003 \\
L.Ln (Z-score) & -0.049 & -0.066 & -0.117 \\
& -0.007 & -0.005 & -0.006 \\
L.NPLs & -0.007 & -0.012 & -0.009 \\
& -0.697 & $-2.309 * *$ & $4.940^{* *}$ \\
L.Inflation & -0.843 & -1.107 & -1.924 \\
& 0.15 & -0.893 & 2.297 \\
L.Real GDP growth & -1.282 & -2.059 & -2.28 \\
& 0.241 & 0.944 & -0.903 \\
Constant & -1.042 & -1.771 & -1.635 \\
& $-0.957^{*}$ & $-1.341^{* *}$ & 0.58 \\
R-sqr & -0.514 & -0.618 & -1.349 \\
Observations & 0.19 & 0.201 & 0.357 \\
Number of Banks & 562 & 271 & 291 \\
Bank Fixed Effects & 21 & 13 & 12 \\
Quarter Fixed Effects & Yes & Yes & Yes \\
\hline Note: The tableprovics & Yes & Yes
\end{tabular}

Note: The table provides information on the regression results of bank capital and liquidity creation relationship. While Column 1 includes all 21 Turkish banks in the sample, Colum 2 and 3 present the results on the small banks and large banks subsamples, respectively. We use lagged independent variables in the models. Bank and quarter fixed effects are employed and bank-level clustered robust standard errors are used. Robust standard errors in parentheses.

$* \mathrm{p}<0.10, * * \mathrm{p}<0.05, * * * \mathrm{p}<0.010$

Our results are inconsistent with Berger and Bouwman (2009) who work on a sample of US commercial banks from 1993 to 2003 and find that the "risk absorption" hypothesis holds for large banks and the "financial fragility-crowding out" hypothesis holds for small banks, contrary to our findings. However, their focus is on the US, a developed market, where the findings are expected to differ from emerging markets due to different institutional environments (Barth et al., 2013). The theories under the "financial fragility-crowding out" and "risk absorption" hypotheses apply to banks of all sizes and it would be quite expected to find varying results for different countries and institutional settings.

For large Turkish banks, we observe that higher capital decreases liquidity creation, consistent with the "financial fragility-crowding out" hypothesis. One important assumption under this hypothesis is that banks gain informational advantages with relationship lending (Diamond and Rajan; 2000). Relationship-specific lending is more relevant for large Turkish banks compared to small banks because investors tend to conduct more trust to large banks and engage in more relationship-specific lending due to weaker corporate governance mechanisms in emerging markets like Turkey. Another important assumption under "financial fragility-crowding out" hypothesis is that more bank equity capital implies fewer bank deposits, which is more relevant for large banks in Turkey. Because large banks in Turkey have more stable asset structures and investing more money in their capital for them would bring a crowd out in deposits, and in their liquidity creation. For small Turkish banks, on the other hand, the "risk absorption" hypothesis is more relevant where higher capital increases liquidity creation. The reason is that smaller banks in Turkey are perceived to be riskier by 
investors and their risk-absorbing capacity is enhanced with more capital which in turn leads to higher liquidity creation.

The results from Table 4 further indicate that some of the explanatory variables are able to explain the liquidity creation of Turkish banks, which include bank size and non-performing loans. While an increase in bank size increases the liquidity creation of banks for the whole sample and "small" banks subsample, bank size does not have a significant impact on liquidity creation for the "large" banks subsample. Moreover, while an increase in NPLs ratio decreases liquidity creation for small banks, a rise in NPLs ratio increases liquidity creation for large banks.

We conduct some robustness tests to verify our findings. These include: i) we include another bank risk measure as a control variable in the model which is the standard deviation for ROA, ii) We include the bank risk measures in the regression one at a time instead of including all of them the model, iii) we include up to four lags other than only the first lag of independent variables. Our findings are consistent with these alternative specifications.

\section{Conclusion}

In this paper, we investigate the influence of the amount of bank capital on bank liquidity creation using a sample of 21 Turkish banks and using quarterly data for the period 2010Q1-2017Q4. Our aim is to see whether more capital decreases the liquidity creation, i.e. the "financial fragility-crowding out" hypothesis holds, or more capital increases the liquidity creation, i.e. the "risk-absorbing" hypotheses is more prevalent for the Turkish context. Empirical support for both strands of the literature is found in our analysis. Specifically, bank liquidity creation is enhanced by more capital for the whole sample, in line with the "risk absorption" hypothesis. When we divide the sample into two subsamples of small and large banks, we observe that higher level of bank capital increases bank liquidity creation for small banks, agreeing with the "risk absorption" hypothesis. Conversely, bank liquidity creation is decreased under a higher level of bank capital for large banks, in line with the "financial fragility-crowding out" hypothesis. Therefore, our analysis indicates that the "risk absorption" hypothesis dominates for small banks and "financial fragility-crowding out" hypothesis is more prevalent for large Turkish banks.

Hence, we find that the link between bank capital and liquidity creation varies by size in the Turkish context which offers some policy implications for emerging markets. The main aim of bank regulators in imposing capital requirements is to preserve the safety and soundness of the banking system. However while capital requirements would bring safety and soundness for all banks in emerging markets like Turkey, the implications for liquidity creation in the economy would differ for banks of different sizes. Specifically, while more capital leads to more liquidity creation for small Turkish banks, it results in reduced liquidity creation for large banks. As indicated by Fungáčová et al. (2017), a decrease in liquidity creation is very important to consider because it could lead to other problems in the economy such as a decrease the amount of financing and a slowdown in economic growth. Therefore, according to our findings, there exists a tradeoff between financial stability and liquidity creation for the case of large banks in emerging markets. The general implication is that, while imposing capital requirements to banks, regulators need to consider the different bank size classes and arrange the regulations accordingly when considering its impact on the liquidity created 
by banks in the system. More stringent capital requirements on large banks could lead to a decrease in their liquidity creation which would hamper economic growth in emerging markets. On the other hand, the more stringent capital requirements on small banks help to enhance their risk-absorbing capacity and increase their liquidity creation by making them safer.

Future research could work on further deepening our understanding of the relationship between bank capital and liquidity creation. The studies could consider using different measures on liquidity creation for Turkey and could evaluate the implications for economic growth and financial stability. Moreover, how much liquidity banks create relative to the nonbank financial intermediaries would be an interesting research question to improve our insight into the liquidity creation function of banks.

\section{References}

Akyüz, Y., \& Boratav, K. (2003). The making of the Turkish financial crisis. World Development, 31(9), 1549-1566.

Allen, F., \& Santomero, A. M. (1997). The theory of financial intermediation. Journal of Banking \& Finance, 21(11), 1461-1485.

Allen, F., \& Gale, D. (2004). Financial intermediaries and markets. Econometrica, 72(4), 1023-1061.

Barth, J. R., Caprio, G., \& Levine, R. (2013). Bank regulation and supervision in 180 countries from 1999 to 2011. Journal of Financial Economic Policy, 5(2), 111219.

Berger, A. N., \& Udell, G. F. (1994). Did risk-based capital allocate bank credit and cause a "credit crunch" in the United States? Journal of Money, Credit and Banking, 26(3), 585-628.

Berger, A. N., Miller, N. H., Petersen, M. A., Rajan, R. G., \& Stein, J. C. (2005). Does function follow organizational form? Evidence from the lending practices of large and small banks. Journal of Financial Economics, 76(2), 237-269.

Berger, A. N., \& Bouwman, C. H. S. (2009). Bank liquidity creation. The Review of Financial Studies, 22(9), 3779-3837.

Bhattacharya, S., \& Thakor, A. V. (1993). Contemporary banking theory. Journal of Financial Intermediation, 3(1), 2-50.

Deep, A., \& Schaefer, G. (2004). Are banks liquidity transformers? (Working Paper Series No. rwp04- 022). Harvard University, John F. Kennedy School of Government.

Diamond, D. W., \& Dybvig, P. H. (1983). Bank runs, deposit insurance, and liquidity. Journal of Political Economy, 91(3), 401-419.

Diamond, D. W. (1984). Financial intermediation and delegated monitoring. The Review of Economic Studies, 51(3), 393-414.

Diamond, D. W., \& Rajan, R. G. (2000). A theory of bank capital. The Journal of Finance, 55(6), 2431-2465. 
Fungáčová, Z., Weill, L., \& Zhou, M. (2017). Bank capital, liquidity creation and deposit insurance. Journal of Financial Services Research, 51(1), 97-123.

Gorton, G., \& Winton, A. (2017). Liquidity provision, bank capital, and the macroeconomy. Journal of Money, Credit and Banking, 49(1), 5-37.

Holod, D., \& Peek, J. (2007). Asymmetric information and liquidity constraints: A new test. Journal of Banking \& Finance, 31(8), 2425-2451.

Horvath, R., Seidler, J., \& Weill, L. (2012). Bank capital and liquidity creation: Granger-causality evidence (SSRN Scholarly Paper No. ID 2178383). Rochester, NY: Social Science Research Network.

IMF, International Monetary Fund (2017). Turkey: financial system stability assessment. IMF Country Report No. 17/35.

Peek, J., \& Rosengren, E. (1995). The capital crunch: Neither a borrower nor a lender be. Journal of Money, Credit and Banking, 27(3), 625-638.

Ramakrishnan, R. T. S., \& Thakor, A. (1984). Information reliability and a theory of financial intermediation. Review of Economic Studies, 51(3), 415-432.

Roy, A. D. (1952). Safety first and the holding of assets. Econometrica, 20(3), 431-449.

Von Thadden, E.-L. (2004). Bank capital adequacy regulation under the new Basel Accord. Journal of Financial Intermediation, 13(2), 90-95.

\section{Appendix}

Table A: List of banks

\begin{tabular}{ll}
\hline Akbank T.A.S. & Sekerbank T.A.S. \\
Alternatifbank A.S. & T.C. Ziraat Bankasi A.S. \\
Anadolubank A.S. & Turk Ekonomi Bankasi A.S. \\
Burgan Bank A.S. & Turkish Bank AS \\
Denizbank A.S. & Turkiye Finans Katilim Bankasi A.S. \\
Fibabanka Anonim Sirketi & Turkiye Garanti Bankasi A.S. \\
HSBC Bank A.S. & Turkiye Halk Bankasi A.S. \\
ICBC Turkey Bank A.S. & Turkiye Is Bankasi A.S. \\
ING Bank A.S. & Turkiye Vakiflar Bankasi T.A.O. \\
Kuveyt Turk Katilim Bankasi A.S & Yapi ve Kredi Bankasi A.S. \\
QNB Finansbank A.S. & \\
\hline
\end{tabular}

Note: This table provides the list of 21 banks included in the sample. 